1992 "Master Frames and Cycles of Protest." Pp 133-156 in Frontiers in Social Movement Theory, edited by Aldon D. Morris and Carol McClurg Mueller. New Haven: Yale University Press.

Snow, David A., E. Burke Rochford, Jr., Steven K. Worden, and Robert D. Benford. 1986. "Frame Alignment Processes, Micromobilization, and Movement Participation." American Sociological Review 51:464-481.

Snow, David A., Louis A. Zurcher, and Sheldon Ekland-Olson. 1980 "Social Networks and Social Movements: A Microstructural Approach to Differential Recruitment." American Sociological Review 45:787-801

Steinberg, Marc W. 1989. “Talkin' Class: Discourse, Ideology, and Their Intersection." Paper presented at conference on "Bringing Class Back In: Contemporary and Historical Approaches," University of Kansas, April 4, 1989.

Tarrow, Sidney. 1989. Struggle, Politics, and Reform: Collective Action, Social Movements, and Cycles of Protest. Western Societies Occasional Paper No. 21. Center for International Studies, Comell University.

1992. "Mentalities, Political Cultures and Collective Action Frames." In Frontiers in Social Movement Theory, edited by Aldon D. Morris and Carol McClurg Mueller. New Haven: Yale University Press.

Taylor, Verta and Nancy E. Whittier. 1992. "Collective Identity in Social Movement Communities: Lesbian Feminist Mobilization." In Frontiers in Social Movement Theory, edited by Aldon C. Morris and Carol McClurg Mueller. New Haven: Yale Univeristy Press.

Tilly, Charles. 1978. From Mobilization to Revolution. New York, N.Y.: Random House.

Turner, Ralph H. and Lewis M. Killian. 1987. Collective Behavior. 3rd edition. Englewood Cliffs, N.J.: Prentice Hall.

\section{CITIZEN-STATE INTERACTION AND TECHNICAL CONTROVERSY: THE U.S. ARMY CHEMICAL STOCKPILE DISPOSAL PROGRAM*}

\author{
ROBERT FUTRELL \\ University of Kansas
}

MARS/Social Thought \& Research, 1997, Vol. 20, No. 1-2

This paper explores the development and transformation of a local collective campaign opposing the U.S. Army's Chemical Weapons Stockpile Disposal Program into a social movement with national and international dimensions. I examine the ways in which the actions of both citizens and the Army bave been shaped by officials, policies and organizations at multiple levels of the state. Contrary to the emphasis on extra-institutional actions noted in many studies of movements and collective action, I show that the social, political and scientific context of technical controversies with the state may place constraints upon and opportunities for action to be directed and sustained through institutional channels. Specifically, I explain the effects of political opportunities, "target vulnerabilities" (Walsh 1986) and specialized resources on the development and transformation of claims-making, forms of action, organizational structure and the expressed aims of the groups involved. I end with suggestions for practical distinctions and refinements in the concepts used in the analysis.

Technical controversies are inherently political (Mazur 1981; Levine 1982; Nelkin 1984; Powell 1984; Jasper 1988; Clarke 1990; Portney 1991; Benford, Moore and Williams 1993; Walsh, Warland and Smith 1993). Since 1970, government regulations over issues of technology and the environment have greatly increased at federal, state and local levels. Citizen protection against environmental hazards and the implementation of controversial technologies has, consequently, depended primarily on government controls (Kraft and Vig 1990). Challengers in technical controversies must often become enmeshed in

* Dr. Jack Weller's sharp insights have been especially helpful for the development of this work. I am also greatly indebted to the anonymous interviewees, without whom this research would have been rather stale and uniformed. This research was supported by a Grant-in-Aid of Research from Sigma Xi, The Scientific Researcb Society. 
institutional politics (see Levine 1982; Gibbs 1982) in order to advance claims and influence decisions. This is especially true in controversies over projects planned by offices of the state. Challengers' ability to advance their claims within institutional channels can be significantly affected by organizational resources such as money, skills, information, and technologies that enhance, for instance, the dissemination of information, legal, political or scientific expertise and organizational structure (McCarthy and Zald 1977; Gerlach 1983; Oliver and Marwell 1992). But, important factors also lie with opportunities external to groups (Tarrow 1994, p.85). Political opportunities in the form of policies, influential allies and state agencies that strengthen challengers' claims can be particularly crucial for understanding how action is shaped through institutional channels and in explaining outcomes in technical controversies.

Broadly, I ask whether controversies over issues of technology and environment involving programs planned by the state, are shaped by influences that may establish similar trajectories of emergence and action across the range of these controversies. Rather than collective action emerging outside the confines of institutional channels, as is suggested by political process analyses (Tarrow 1994, 1989; Tilly 1978; Lo 1992), my study suggests that protest in technical controversies may tend to develop within and remain focused on institutionally mandated channels for political participation. This is due, in large part, to state policies and regulatory mechanisms, actions of political officials and occasions for public participation that both constrain and enable the actions of challengers and the challenged in several ways.

Specifically, this paper examines the interaction between citizens and the state through successive phases of the controversy over the United States' Chemical Stockpile Disposal Program. I focus on the manner in which political opportunities created by state policies, influential allies and actions by agencies of the state at various levels have shaped the actions and claims-making of both the movement and the Army. I explain the factors that led to the emergence of the citizens' challenge to the Army's proposal and the initial dimensions of political opportunity. Then, by describing multiple phases of the controversy I show how the initial dimensions of opportunity changed over the course of the dispute and why transformations in strategies the movement pursued emerged as it developed from a localized controversy to a social movement with national and international ties and implications. I describe the way in which federal guidelines associated with the National Environmental Policy Act of 1969 (NEPA) provided a framework that conditioned the actions and claims-making of citizens, political officials, the Army and other agencies of the state in their attempts to influence the trajectory of the disposal program. I explain the movement's adjustments to changes in dimensions of opportunity, associated changes in strategies toward an emphasis on marshalling specialized resources such as technical experts and scientific data, and their effects on the claims and actions of the movement and its organizational arrangements. I also address the effects of human errors and technical problems associated with the disposal program on both the Army's and the movement's claims-making and actions.

Conceptualizing, understanding and explaining political opportunity is central to the analysis. But as Gamson and Meyer (1996, p.275) have noted, "the concept of political opportunity...is in danger of becoming a sponge that soaks up virtually every aspect of the social movement environment." In this paper political opportunities is used as a sensitizing concept that illuminates a number of influences on the citizens' challenge to the disposal program. I take the position that opportunities can emerge in many forms and the influence they have on the actions and development of movements is variable. The assumption is that in some cases it is quite possible that political opportunity may not exist in a readily definable form or may fail to provide a robust explanation for movement actions. Consequently, the existence and importance of political opportunity for analyzing and explaining movement actions may best be left open to explanation in relation to the particularities of a specific case or sets of cases. Attempts at broad generalization runs the risk of quickly overstepping the bounds of the concept's explanatory potency.

As this case shows, focusing on dimensions of political opportunity is useful not only for analyzing broad movements or national cycles of protest, but also the developments of localized controversies into social movements. Examining case-specific particularities of political opportunity allows for practical refinements and distinctions to be made among the broad dimensions of opportunity described by Tarrow (1996, 1994, 1989) Tilly (1978) and others. The technical nature of the controversy and the institutional channels through which action may be directed are especially important for understanding political opportunities and collective action in this case.

\section{Political Opportunities, Target}

Vulnerabilities and Repertoires of Action

Tarrow (1994, p.85) suggests that political opportunities are "dimensions of the political environment that provide incentives for people to undertake collective action by affecting their expectations for success or failure" in gaining political leverage for their claims. 
Dimensions of opportunity vary at different levels, across localities and among agencies and levels of the state $^{1}$ (Tarrow 1994, p.18). Opportunity may expand as access to political participation increases, reform legislation is approved, political alignments shift, influential allies are coopted or as the aims of officials and agencies conflict, both within and between levels of the state (Tarrow 1994, pp.85-89; also see Walton 1992). The fluid character of political opportunities makes "more solid resources" important, for they enhance a movement's capacity to capitalize on emerging opportunities and "prevent [others] from slipping away" (Tarrow 1994, p.99). Three are particularly important: claims that legitimate collective action, a flexible repertoire of action and organizational structures that guide interaction by actors at the movement's base, while maintaining interaction with allies and opponents (Tarrow 1994). Each of these was significant in the development of the dispute over the disposal program.

Particularly relevant to the emergence of opportunities in technical controversies are "target vulnerabilities" (Walsh 1986). Walsh suggests that a target's "own human and technological weaknesses" can expose problems around which critical claims can be made or that may substantiate claims previously made about the technology being challenged. Exposing these weaknesses can expand political opportunities for challengers by de-legitimating opponent's claims to authority or providing incentives for political actors and allies to intervene. $^{2}$ Both human errors and technical problems associated with the Army and the disposal program have had significant influences on the movement's claims-making and actions.

Mobilizing movement participants and influencing state actors and agencies is most often carried out through forms of collective action that address state systems in ways that will be acknowledged and compel response (Tilly 1978; Cable and Benson 1993; Tarrow 1994). Challengers have access to and often combine a variety of existing forms of collective action. The shifting character of political opportunities

1 The state is understood here as a multi-dimensional ensemble of actors, agencies and offices interacting at many levels and across localities. Its policies are often contested and influenced by a complex of competing interests. This multi-dimensional form can provide numerous targets for claims-making, potential allies and points of access that facilitate collective action.

${ }^{2}$ It is also quite conceivable that in certain situations unsubstantiated claims of the challengers could have the reverse effect. As with political opportunity, target vulnerability should be understood as a sensitizing concept that aids the researcher in formulating questions about particular cases and series of collective actions. favors a flexible repertoire that changes through innovation, imitation of other groups, and as participants, interests, opportunities and goals change (Tilly 1978; Tarrow 1994; Turner and Killian [1957] 1987). The fluid and emergent grounds on which movements develop (Weller 1994) push conventional forms of action to repeatedly be "redeployed, tinkered with and combined" (Tarrow 1994, p.114). One of the foremost challenges for movement organizers then "is to create organizational models that are sufficiently robust to stand up to opponents, but flexible enough to change with new circumstances, [favor a flexible repertoire of action] and draw on energies at the base (Tarrow 1994, p.136)."

The focus on political opportunities, target vulnerabilities and repertoires of action is particularly useful for understanding the institutional channeling of action that characterizes this technical controversy. There are a multiplicity of social, political and scientific issues inherent to technical controversies to which challengers may address opposition toward projects and shape their design and implementation. To push their claims challengers must, to some extent, maneuver within institutional channels with respect to government controls that shape decision-making processes involving controversial technologies. These institutional channels provide initial points of access to decision-makers among multiple agencies and levels of the state that can be exploited to challenger's own ends. In addition, once the technical nature of a dispute has been given legitimacy by the agencies and officials involved in the dispute, decision-makers are moved to act on the basis of technical evidence. Challengers are then faced with the task orienting their repertoire of action toward assembling and presenting technical evidence to justify their claims. Here target vulnerabilities may become especially significant for legitimating opposition by providing key empirical referents that further problematize the development of the project and technology being challenged. As this case shows, these dimensions of technical controversy may be critical for explaining the development, transformation and endurance of collective action in these disputes.

\section{Data and Methods}

Data were gathered from all available secondary sources to verify accounts of actions and events over the course of the controversy. Newspaper reports and publications of citizens' groups, environmental organizations, U.S. Army and other federal agencies supplement primary data from interviews and field observations. Over 500 news articles 
from local, regional and nationally distributed newspapers ${ }^{3}$ were collected, providing the chronological ordering of events and actions and indications of the media's portrayal of the controversy over time. Newsletters, informational packets and reports produced by citizens groups in Kentucky, Utah, Maryland, the Pacific Islands and Russia were also used. These documents yielded information on the discursive framing (Snow, Rochford, Worden and Benford 1986) of the controversy by the groups, strategies, actions, resources and foci of action at different periods of the controversy. Reports and newsletters of larger environmental groups, such as Greenpeace USA, Sierra Club, National Toxics Coalition, the Government Accountability Project, and the Kentucky Resources Council and private correspondences between these groups and local organizations were also used. These documents helped to indicate sources of modifications in the action repertoire of the opposition, claims-making and resources, as well as evidence of the social and organizational networks in which local challengers were located during the controversy. Documents produced by the U.S Army, the National Research Council, the Commonwealth of Kentucky, and the Office of the Federal Register, National Archives and Records provided important information on the expressed positions various state organizations, interactions among them, regulatory constraints they faced and data used to support their claims. ${ }^{4}$

Intensive interviews were done between June 1994 and May 1995 with seventeen key participants in the citizens' groups challenging the disposal program. Interviewees were among the most active members in the Kentucky groups, as well as the broader coalitional networks influencing the movement. They provided information on intraorganizational discourse, changes in repertoires of action, bases for transforming the organizational structure of the movement and the types of resources embedded in the networks of participants from which the movement drew, especially in the initial phases of the controversy. As principal participants throughout multiple phases of the controversy, their accounts are vital for understanding these influences on the

${ }^{3}$ Articles were collected from The Ricbmond Register, The Berea Citizen, The Eastern Progress, The Lexington Herald-Leader, The Courier Journal, The Cincinnati Enquirer, The Baltimore Sun, The Oregonian, The New York Times and The Washington Post.

${ }^{4}$ The conclusions reached are necessarily confined to assessment of issues, actions and developments as captured by media representations, institutional discourse and action, and the discourse and actions of movement organizations as expressed in their documents and the views of a limited number of key participants. No attempt is made provide an understanding or explanations regarding the ideas, perceptions, actions or interests of actors or organizations beyond the discursive and documented representations afforded by the data.
Citizen-State Interaction movement and provide a means to assess internal responses of the groups to changes in dimensions of political opportunity. ${ }^{5}$

\section{Creating Opportunities: The National \\ Environmental Policy Act of 1969 and the Reagan Years}

Political interests and governmental regulations have significantly shaped the chemical weapons disposal controversy by their impacts on the structure of political opportunities facing the citizen challengers. Some of these influences can be traced back more than a decade before the dispute began in Madison County, Kentucky.

During the 1970's environmental issues enjoyed intense public interest leading to major federal policy revisions (Bosso 1991, p.155). Congress set the stage for these innovations at the end of 1969 when it passed the National Environmental Policy Act (NEPA, P.L. 91-190) (Vig and Kraft 1990) requiring detailed environmental impact statements (EIS) on any "major federal actions affecting the environment" (Congressional Quarterly Almanac 1970, p.525). During the next decade detailed guidelines for EIS's were set out by the President's Council on Environmental Quality (Kraft and Vig 1990, p.17; Wenner 1990). The National Environmental Policy Act of 1969 and the Council on Environmental Quality mandated that public hearings be provided for citizen participation in developing environmental impact statements. These institutionally mandated hearings expanded points of access to authorities by providing channels of communication and have subsequently conditioned challenges to controversial technologies to emerge within these hearings and to be shaped by the broad framework of NEPA procedures.

Congress maintained a commitment to environmental issues throughout the Nixon, Ford and Carter administrations. However, by the mid-eighties the Reagan administration had reduced the ability of federal agencies to enforce environmental regulations (Vig 1990; Bosso 1991). Cutbacks in budgets and staffing and reductions in the scope of

\footnotetext{
${ }^{5}$ Each interview was tape recorded and was approximately two hours in length. The interviewees' observations represent a relatively small proportion of individuals involved in the issue and may or may not fully reflect others' perceptions of events. However, the interviewees were among those in positions to know of and understand important factors interviewees were among those in positions to know of and understand important factors
behind the actions, strategies and discourse of the citizens' opposition and the influences that helped to transform these throughout the controversy. It is quite probable that those interviewed have partially reconstructed their understandings of motives and occurrences in light of later events. But by cross referencing these observations with the myriad secondary sources gathered, as well as field notes and other interviews, this work reflects the history and actions of the twelve-plus year controversy.
} 


\section{MARS/Social Thought do Research}

authority for many federal agencies have led to increased autonomy of state-level agencies and local governments to set and enforce environmental policy. A result has been the development of policies at some state and local levels that surpass many federal regulations (Lester 1990). The Army's announcement in 1984 of their proposal to incinerate chemical weapons in Madison County, Kentucky and seven other sites around the country ${ }^{6}$ came in the midst of Reagan's devolution of environmental policy development and enforcement.

\section{Institutionalized Opportunities and Local Alliances}

During the earliest phase of the controversy, actions of both the citizens and the Army centered on the development of the required Draft Programmatic Environmental Impact Statement (Draft Programmatic EIS). Public meetings required by NEPA policy provided initial points of institutional access to political actors and occasions for citizens to critically assess the Army's proposal. Citizens in Madison County, Kentucky began to organize following the Army's first meeting and allies at the local, county and state levels emerged. The actions of the nascent alliance resulted in the first set of delays for the Army's disposal program.

Following NEPA requirements, the Army set out in 1984 to construct a Draft Programmatic Environmental Impact Statement for the chemical weapons disposal program. The Draft Programmatic EIS is the initial phase required in the development of a final EIS. It allows a project's sponsor a period to gauge public opinion and determine the types of information needed to evaluate the possible environmental effects of the project and, consequently, an opportunity for opponents to mobilize. Meetings at each site marked for an incinerator facility were conducted as the public participation component of the Draft Programmatic EIS (Federal Code of Regulations, 651.35 - 651.41, 1991). The meeting in Madison County on February 16, 1984 was crucial to the emergence of local challenges to the Army's plans for constructing a chemical weapons disposal facility at the Blue Grass Army Depot in Richmond, Kentucky.

${ }^{6}$ There are eight sites in the continental U.S. where differing percentages of the nation's chemical weapons stockpile is stored and slated for incineration facilities under the Army's proposed plans: Aberdeen Proving Ground, Aberdeen, Maryland (5.0\%); Anniston Army Depot, Anniston, Alabama (7.1\%); Lexington Blue Grass Amy Depot, Richmond, Kentucky (1.6\%); Newport Army Ammunition Plant, Newport, Indiana (3.9\%); Pine Bluff Arsenal, Pine Bluff, Arkansas (12.0\%); Pueblo Depot, Pueblo, Colorado (9.9\%); Tooele Army Depot, Tooele, Utah (42.3\%); and, Umatilla Depot, Umatilla, Oregon (11.6\%) (NRC 1994).
Citizen-State Interaction

Because of earlier incidents local concem about Army operations at the Madison County storage facility existed prior to the meeting, providing some incentive for local citizens to attend and question the Army's proposal. Some of the 300 citizens in attendance questioned the Army's representatives about the safety of incineration, alternatives to on-site disposal and the possible future-uses of the facility after disposal was completed. Competing claims were presented about the potential options for dealing with the local stockpile. Incineration was touted by the Army as the safest, most efficient and effective means of disposal. But Kentucky officials, local politicians and several citizens, including professors, physicians and an environmental engineer were quick to challenge, suggesting that alternatives were available. Army officials appeared unprepared and uninterested in the citizens' concerns. Impressions emerged that the Army's plan was in fact compulsory rather than open to discussion and change, as the Army had implied in calling for public participation.

The institutionalized occasion of the meeting allowed direct interaction among Army spokespersons, citizens and political officials, resulting in the emergence of a conceptual foundation for future action. Citizens began to construct a discourse that was highly critical of the Army and depot operations. "Public participation" was regarded as flawed from the beginning by the Army's callous disregard of citizens' concerns and its failure to view incineration as merely one of several options for disposal. Citizens began to organize following the meeting.

Tilly (1978, pp.156-159) explains that "prevailing standards of rights and justice" and citizens' prior experiences "govern the acceptability" of various forms of action to both citizens and states. Most local citizens involved in the first opposition group to be formed, Concemed Citizens of Madison County (hereafter noted as Concerned Citizens), had little experience in collective action. Many were, however, quite experienced in local and state-level politics. Participants in the Concerned Citizens assumed the political nature of the issue and acted in ways familiar to them. Information about the Army's proposal and legal approaches to blocking the plan were sought. Local, state and some federal officials were quickly contacted and urged to oppose the plan. The most publicly visible actions of the Concerned Citizens during this period were oriented towards participation in public meetings mandated by NEPA or organized by political officials. Between meetings their focus moved to lobbying strategies and legal approaches.

An alliance between the Concemed Citizens and some local, state and federal officials emerged early in the controversy. The alliance provided the Concerned Citizens early points of access to political allies 
at multiple levels of the state. Within the first six months legislation was written to impede the Army's gaining approval for necessary Kentucky emissions permits. Local courts called for a congressional investigation into the Army's proposal and established an ordinance banning chemical weapons from Madison County. By June U.S. Congressman Larry Hopkins, whose district included Madison and surrounding counties, had organized the Madison County Task Force, a group staffed by local citizens and officials to study the Army's proposal and make recommendations to his office and the community.

Leaders of Concerned Citizens expressed confidence that these actions, especially the Task Force, were important indications of government support for local concerns and reported a sense of efficacy among the group regarding its position and actions. Support from political allies and the apparent efficacy of their actions would serve to further the Concerned Citizens' focus on institutionalized means fo affecting the Army's program. The Army also helped to solidify this focus. Army discourse stressed on-site incineration as the preferred method of disposal. But, it was repeatedly stressed that, as mandated by NEPA, citizens' concerns would be influential in decision-making regarding the project and alternatives to incineration would be considered before action proceeded. A number of altematives to on-site incineration, including transportation of the Kentucky stockpile to a prototype disposal facility in Tooele, Utah, were mentioned by Army officials as workable. Citizens and political officials began to emphasize the option of transportation and during the first months of the controversy a not-in-my-backyard (NIMBY) position became central to
the local opposition.

Local opposition to on-site incineration prompted the Army to delay the release of the Draft Programmatic EIS indefinitely. The delay bolstered the credibility of the challengers' claims with local and statelevel political officials and media. The delay also provided the Concerned Citizens time to further consolidate support of political officials and other allies. Political opposition to the program appeared quite strong when, less than six months after the first public meeting Congress suspended funding for the Kentucky facility. But, in November 1984 the National Research Council recommended But, in Army proceed with on-site incineration (National Research Council 1984).

Throughout 1985 and 1986 citizen participation remained high and lobbying efforts and public meetings continued. For example, a meeting organized by the Task Force in January 1985 drew over 500 citizens to listen to Army representatives present the National Research Council's recommendations and intensely question them for over two hours. Incineration continued to be emphasized in the Army's proposals, but transportation was also presented by Army representatives as a workable alternative. Moreover, an Army-commissioned study on disposal technologies by the Arthur D. Little Company released in mid-1985 supported neutralization technology and indicated that its estimated costs were far below that of incineration. The report was incongruous with the Army's rationale for on-site incineration. As a result, a member of the Concerned Citizens recalled that these differing claims meant for citizens that, "...in the early period of about a year or so things weren't getting more clarified but were getting more obfuscated if anything" (interview 6/7/94).

Competing claims about options for the Madison County stockpile continued through 1986. In May 1986, the Madison County Task Force released its own detailed report informed by data from community proposals, Army risk analyses and prior research on alternatives to incineration. The report recommended transportation, over on-site incineration. It appeared to have little effect. On July 1, 1986, the Army released their Draft Programmatic Environmental Impact Statement supporting on-site incineration.

The Draft Programmatic EIS was not well received in Madison County. The local hearing organized for the public release of the document lasted over six hours (Hindman 1989). Citizens claimed that the Army gave only cursory attention to transportation. The Concerned Citizens brought legal experts in environmental law from the Kentucky Resources Council and scientists from two regional universities who made detailed comments highly critical of the Draft Programmatic EIS. The critiques focused on the construction of the document, its conceptual foundation and the technical procedures used to develop the data on which the report was based (Hindman 1989, p.292). An especially controversial topic was the programmatic orientation of the EIS that failed to assess each site individually. ${ }^{7}$ In a subsequent congressional field hearing on the disposal program, Congressman Hopkins expressed a common criticism.

7 Programmatic reviews are encouraged "when programs are being considered for general application (Code of Federal Regulations, 1991, section 651.12)." In effect this meant that the Draft Programmatic EIS for the disposal program would be a generic (programmatic) approach to studying possible environmental impacts of the Chemical Stockpile Disposal Program. No site, in spite of their unique features, would be reviewed alone. Instead the approach was more akin to averaging or blending the characteristics of the various target communities and their environs into generic communities for comparison of impacts. Hence, not only would the study be generic but the decisions made would apply across the board as well. 
Translated into plain language 'programmatic' means the Army took all eight sites in the United states where chemical weapons are stored, lumped them together, ran them through a computer, hired some consultants to interpret the results, and then hired an expert in double talk and government euphemisms to write a report hardly anyone could read, much less understand (Transcript of Field hearings of Investigations Subcommittee of House Armed Services Committee 7/25/86).

An attorney for the Kentucky Resources Council described the Draft Programmatic EIS as conceptually flawed with significant gaps of information; "so flawed that it [would be] impossible to patch it up (Register 8/29/86)." Discrepancies between claims and actions of local citizens, state political actors and the Army were central issues of contention.

During this early phase NEPA requirements provided an institutional framework for citizen opposition to Army's disposal program. The Army was bound to the phased process of constructing impact statements with mandated public input. Rather than extrainstitutional protest, actions of the Concerned Citizens were centered by the institutionally mandated public forums, while lobbying activities dominated between meetings. Army betrayal of assurances of public participation became a central claim expressed in the public meetings and corresponded with the view expressed by political officials and other citizens. $^{8}$ Transportation, Concemed Citizens' preferred option, was encouraged by the Army's repeated indications that it was a workable alternative. Congressman Hopkins' Task Force furnished local citizens with further opportunities to attempt to influence the decision-making process regarding the Army's plan. Consequently, public opposition to the disposal program was quite strong in Madison County, but collective action remained sporadic and limited to state legitimated forms of citizen action (Tilly 1978, p.156).

Tarrow (1994, pp.106-114) suggests that nascent movements tend to engage in distuptive, extra-institutional forms of action that, through sustained interaction with authorities, may develop into more cooperative, institutionalized forms. In this controversy, however, collective action began through institutionalized politics and channels, not extra-institutional protest. Public hearings provided institutionalized means of access to authorities and, ostensibly, to participation in decision-making on plans for weapons disposal. The Army was not responsive to citizen concerns and the dispute was not resolved. As the

${ }^{8}$ In this period, claims-making regarding the Army's plans concerned primarily the design of the disposal progtam, specifically the programmatic ocientation of the Draft Programmatic EIS and on-site disposal, rather than the disposal technology to be employed. controversy proceeded, repeated failures of citizens' attempts to affect decisions through channels for participation mandated by Congress and NEPA procedures justified claims of Army disinterest in local concerns. Reports and testimony indicating the workability of several altematives to the Army's plans for stockpile disposal were influential in affecting actions and claims-making. Incongruities in the Army's stance opened the Army to highly critical claims against the proposed design of the disposal program by both citizens and officials. As a result the citizens' challenge gained an expanded set of political allies opposing chemical weapons incineration in Madison County.

\section{Emergent Vulnerabilities and the Final Programmatic EIS}

Following the release of the Draft Programmatic EIS, the next step for the Army was to construct a Final Programmatic Environmental Impact Statement (Final Programmatic EIS). The Final Programmatic EIS was intended to be the Army's final decision on the technology to be used and sites to be involved in the disposal program.

In early 1987 two new groups entered the controversy. The Army funded the formation of the Community Review Team, a new, independent, community-based study group supported by Army finances and research information. The group's purpose was to relay local concerns about the disposal plan to the Army as the Final Programmatic EIS was developed. The contract signed with the Army on January 23, 1987 "provided $\$ 116,000$ for salaries, travel funds and consultants and required a final report by September 30,1987, to become part of the Final Programmatic EIS then scheduled for January 1988" (Hindman 1989, p.293). Also, because of both geographic and ideological differences, about ten Berea, Kentucky residents split from the Concened Citizens to form Common Ground, based in Berea. ${ }^{9}$ Common Ground's founders reportedly sought to create a more participatory organization to involve more citizens in the controversy and develop strategies to complement those employed by the Concerned Citizens.

Despite the emergence of these new organizations, 1987 was a year in which citizen opposition might have declined. No new decisions were

9 The Blue Grass Amy Depot in Madison County is located between Richmond and Berea, Kentucky. Concerned Citizens of Madison County was a Richmond based group and reflected the historically conservative atmosphere of that community. Common Ground is based in Berea and likewise reflects the historically liberal tenor of the area. For more about these differences see, William E. Ellis', H.E. Everman's and Richard D. Sears' 1985 book Madison County: 200 Years in Retrospect. 
scheduled to be made on the chemical weapons disposal program during the year. But, on January 28, 1987, three mechanical problems resulted in an atmospheric release of nerve agent at the Tooele, Utah, facility. As is often the case with accidents involving complex technologies, the incident was blamed primarily on operator error (Perrow 1984). However, federal investigators also found "numerous shortcomings in the way the whole nerve gas program was being run", criticizing communication between employees and superiors, deadline pressures, lack of adequate supervision and delays in reporting similar incidents (Herald-Leader 9/20/87).

The Tooele incident was significant in two ways. First, days following the release of the report on the incident in September, the Army called a public hearing in Madison County in an attempt to quell public concerns over the event. The meeting provided an occasion for local organizations to mobilize citizens at a time when none had been previously scheduled. As a result, the frequency of Common Ground meetings increased and meeting attendance grew. Second, the incident again expanded the opposition's set of critical claims against the Army. New facts supported accusations of Army negligence, mismanagement and inadequate technology. Both Concemed Citizens and Common Ground touted the incident as strong evidence against on-site incineration in the highly populated area of Madison County, Kentucky.

Less than a month after the September, 1987, hearing on the Tooele incident, the Army-financed Community Review Team released their report. It recommended air transport of the Madison County stockpile to the Tooele, Utah site. Concerned Citizens and Common Ground members expected the report to be more influential with both Army officials and political policy-makers than the earlier report by the Madison County Task Force. The expectation was inaccurate. The Community Review Team provided a new channel for citizen-Army communication and ostensibly a new means by which citizens could affect the disposal program. But, in January 1988, the Army released the Final Programmatic EIS supporting on-site incineration for all eight sites, including Madison County.

Following the release of the Final Programmatic EIS, Congressman Hopkins called a public meeting to be held during a NEPA mandated 45-day public comment period following the release of the document. The comment period provided citizens time to organize action and the public meeting provided the occasion, now quite familiar to the challengers, in which to act. The January 29, 1988 meeting drew over 2,000 people who overwhelmingly expressed opposition to the Army's decision. Following the hearing, the Army delayed indefinitely the final Record of Decision on the project.

The hearing marked the beginning of a transformation in the politics of the disposal program. Political allies were gained at the state-level as, by mid-1988, many Kentucky officials from the Governor down were on record opposing on-site incineration in Madison County. The Kentucky General Assembly passed new legislation that allowed local fiscal courts to prohibit construction or operation of incineration facilities within their jurisdictions and that classified chemical munitions as hazardous material, requiring the Army to comply with federal and state-level regulations for hazardous waste disposal.

Although the Army's disposal program included eight sites, resistance remained confined to the local controversy in Kentucky. Intense opposition at one site hadn't halted the Army's programmatic emphasis regarding the impact statements and federal budgetary appropriations for the program remained unchanged. The Army's 1988 Programmatic Final Record of Decision remained firm in the selection of on-site incineration for all sites. NEPA policy and the Federal Code of Regulations, however, includes provisions for Site-Specific EIS's if the sites involved in project can be shown to differ to an extent that might confound programmatic conclusions. The institutional framework of NEPA continued to shape the actions of the Concerned Citizens, Common Ground and their allies as they pressed the Army to implement the site-specific stage. The groups expressed the expectation that a new assessment would clearly show that on-site incineration was not appropriate for the highly-populated Madison County, Kentucky area.

Shortly after the release of the Programmatic Final Record of Decision, the Army announced that it would pursue site-specific statements thoroughly reevaluate previous EIS's and options such as transportation or neutralization for each site as the challengers had hoped, the Army explained that the Site-Specific EIS would determine only the specific location at each depot on which the incinerator facility would be constructed. Other options would be considered only if new technical evidence was presented that warranted reconsideration of on-site incineration.

Political support had expanded at different levels, sustaining action Kentucky by Concemed Citizens and Common Ground, but not across the localities implicated in the disposal program. The Army's Final Record of Decision made clear that organized opposition to on-site Final Record of Decision made locale involved in the disposal program would not halt the advance of the disposal program. The Army had bounded 


\section{MARS/Social Thought \&o Research}

subsequent debate over the program (Davies 1995). Critical claims over the construction of the Army's environmental impact statements and the option of transportation were no longer to be considered. Rather, only evidence and claims regarding the complex technical aspects of the program were given legitimacy by the Army. Further action and claims challenging the Army's plans for disposal were to be limited largely to scientific and technical issues regarding how best to incinerate, not whether to do so. This shift, in effect, diminished the expected impact and opportunities provided by the Site-Specific EIS request and prompted a series of changes in the forms of action, organization and claims-making pursued by the Concerned Citizens, Common Ground and their allies.

In sum, shifts in the accessibility of institutional channels through which the citizens' challenge could be directed and the conditions under which it could take place continued to shape the trajectory and profile of collective action. Changes in citizen action, organization and claimsmaking through the ensuing phases of the controversy emerge, in large part, as responses to the Army's maneuvering within the institutional requisites of NEPA and the EIS guidelines toward emphasizing debate on the technical features of the disposal program. As institutional opportunities for affecting decisions made on the disposal program shifted, collective action, organization and claims-making began to be transformed as well. These transformations would recursively affect the actions of the Army and other agencies of the state.

\section{Shifting Opportunities, Vulnerabilities and the "Growth of Protest"}

During 1989 Concerned Citizens and Common Ground were in a wait-and-see mode while the Army began the process of developing the site-specific impact statements. But, new influences, seemingly far removed from the local protest over weapons disposal, began to influence the controversy. As U.S.- Soviet relations began to thaw in the mid-eighties, agreements were reached by the Reagan administration to withdraw the NATO stockpile of chemical weapons from Europe by 1992. Also, in 1987 Russia had initiated a series of policy reversals, one of which was to terminate their production of chemical munitions (Robinson 1993). Although no workable disposal system was in place, the governments tentatively agreed in 1989 to reduce their chemical weapons stockpiles $80 \%$ to $90 \%$ over a ten year period beginning in 1992 and to cease further production. The agreement established ties between the two superpowers on the issue of chemical weapons disarmament. It also demonstrated further discrepancies between federal level policymaking and citizen interests at local and state levels. Concerned Citizens, Common Ground and others had not opposed the ends of destroying the
Citizen-State Interaction

U.S. stockpile of chemical munitions but the design of the Army's program, specifically on-site incineration. The timeline of the U.S.Soviet agreement rested on the timely implementation of the Army's existing design of the program.

Between 1988 and 1990 opposition to the disposal program had also increased among the U.S. sites. Citizens in Indiana and Maryland had begun local organizing efforts. Residents of Hawaii, Micronesia, Polynesia and the Marshall Islands were also beginning to organize local challenges to the Army over the transportation of the NATO stockpile to Army's incineration facility on the Johnston Atoll in the South Pacific. The U.S.-Soviet accord had also prompted an expansion of citizen opposition to incineration in Russia. In Kentucky, the Concemed Common Ground began to expand their network of affiliations by interacting with larger environmental groups, such as Greenpeace, the National Toxics Campaign Fund and the Citizens Clearinghouse for Hazardous Waste. These multiple affiliations would open access to new information and resources for Common Ground to draw upon in addressing the Army's technical claims for incineration.

Transportation of the NATO stockpile was claimed by the citizen challengers to be a fundamental contradiction to the Army's persistence for the development of on-site incineration in the U.S. The issue opened the Army to new criticisms that were amplified when, in April 1990 , "technical problems" and "safety considerations" at the Johnston Atoll facility pushed the Army to delay further action at the eight continental incinerator sites (Herald-Leader 4/6/90; Richmond Register 4/6/90). These developments were used by Common Ground and Concemed Citizens to further claims opposing incineration in Madison County, Kentucky.

But a report released by the U.S. General Accounting Office in June 1990 charged community opposition groups with "impeding" implementation of the disposal program by forcing repeated delays and implemint costs of the program. Kentucky's stringent new increasing costs of the program. Kentucky's stringent new environmental regulations and lack of federal appropriations for the program were also cited as significant factors for the delays. In Kentucky, the report brought public expressions of resentment and Kentucky, the officials. Contradictions between the claims and actions of agencies at the federal level and those at the state and local levels were again apparent. The delays in the disposal program could, however, also be explained by repeated operator errors and technical problems at the Tooele and Johnston Atoll test errors and technical problems at the Army vulnerable to critical claims-making 
MARS/Social Thought \& Research

regarding the human and technological inadequacies of the program. These vulnerabilities provided opponents added opportunities to further consolidate political support and indications of new political allies began to emerge. 10

\section{Coalitions and Strategic Transformations}

As the controversy moved into the 1990 's, opposition to the U.S. disposal program began to expand as multiple sites implicated in the Army's continued to organize. ${ }^{11}$ In light of the opposition's failure, thus far, to fundamentally alter the Army's program, leaders in Common Ground began to discuss the political effects of national and international organizing to oppose chemical weapons incineration. Debate among members of Concerned Citizens and Common Ground was contentious, but in 1990 two members of Common Ground founded a non-profit organization, the Kentucky Environmental Foundation (KEF). KEF was intended to provide financial and informational support to local groups at other sites implicated in the disposal program. The organizational changes in Kentucky would prove influential in expanding political opportunities. New information, resources and other forms of support provided a foundation for citizens' groups at other sites to organize, gain influence among political officials and create multiple points of access to local, state and federal-level policy-making processes. The expansion in channels of communication and access to officials, across localities, enhanced citizens' influence on political actions at multiple levels of the state.

The Army's ability to effectively bound debate over the Site-Specific EIS prompted the Concemed Citizens and Common Ground toward strategies for assembling new forms of evidence that would counter the Army's push for incineration as the technology of choice. Citizen leaders in Common Ground and KEF also began to establish new coalitions and

${ }^{10}$ In August 1990, dissatisfied with the earlier GAO report, Senator John Glenn (D-Ohio) and Representatives John Conyers (D-Mich.) and Earl Hutto (D-Fla.) initiated a follow-up review. The new GAO study concluded that the Johnston Atoll facility (and the entire disposal program) was over-budget and delayed because of technical and and the entire difficulties rather than the citizens opposition. The reperanical and organizational overcharges and poor monitoring of the facility's const report cited contractor malfeasance, process. Earlier cost estimates for the projectity's construction as important factors in the over $\$ 190$ million for the Johnston Island facility were also recalculated, showing increases of

11 In addition to Indiana, Maryland and the Pacific Islands, organized opposition to the disposal program had expanded to include the sites in Alabama, Arkansas, Utah and Oregon.
Citizen-State Interaction

explore new strategies for influencing and gaining political allies at multiple levels of the state and across localities. Common Ground entered an established coalition of national anti-toxics and antiincineration groups in 1990. The new networks expanded Common Ground's and KEF's access to information and experts and created symbolic ties with established national organizations. But, as is typical in many community-based technical controversies, Concerned Citizens and Common Ground still retained much of their local focus (Brown and Masterson-Allen 1995). Excluding on-site incineration in Madison County from the Army's plans and emphasizing transportation of the Kentucky stockpile to the Tooele, Utah facility remained the primary aim of the Madison County groups.

Citizen strategy showed signs of transformation at the end of 1990 . During the first six years of the controversy the Concerned Citizens and Common Ground had been consistently engaged in reactive actions conditioned by opportunities provided by NEPA regulations and associated public meetings arranged by the Army, political officials and the publicly-funded study groups. But now, rather than waiting for the Army or political officials to call another public meeting, Concerned Citizens and Common Ground organized their own in October 1990. With the help of Greenpeace, the groups brought two internationally renowned experts on incineration, toxic waste disposal and dioxin contamination who advanced highly critical, technical analyses of the disposal program and spoke of possible altematives to incineration. The experts supported the opposition's position by legitimating common claims with new, technical information. The centerpiece of the citizens' action repertoire, the public meeting, was preserved in form but the content had been altered. The meeting indicated an opposition in the process of refining its repertoire in pursuit of more pro-active, solutionoriented claims-making and actions.

Further transformation in the citizens' strategy was apparent at the Army's first scoping meeting for the Site-Specific EIS in April 1991. Concerned Citizens and Common Ground, in conjunction with technical experts, environmental groups and the Kentucky Resources Council, systematically constructed a series of arguments precisely detailing the citizens' oppositional stance. Almost 1,000 people heard the Concerned Citizens and Common Ground leaders present arguments titled "The Citizens' Viewpoint". As a KEF member explained,

["The Citizens' Viewpoint"] was the first time that the citizens put together their views in a very aware kind of way [and] dealt with the alternatives that are available according to data from Greenpeace...and other experts (interview $5 / 8 / 95$ ). 
The citizens' were modifying the repertoire as new forms of action were combined with older, more familiar forms. The position paper was a new addition to the public meeting and provided an important means for expressing the collective identity of the opposition, strengthening lobbying efforts and expanding the political salience of their claims. Also, technical knowledge gained locally and through resources located within their expanding network of affiliations was increasing and being incorporated into the claims-making and actions of the citizens groups.

Spurred on by the internal leadership, Common Ground and KEF had taken the lead roles in organizing citizen opposition. Despite some objections by the Concerned Citizens cadre, they had begun to promote a national focus as they more seriously considered the political influence that a coalition with the other sites could provide. The Department of Defense had provided an important precursor to this new emphasis when it held the 1990 Symposium on the Environment that drew representatives from each of the eight sites involved in the disposal program together. Interaction with citizens from other sites obliged the Madison County delegates to reconsider their not-in-my-backyard (NIMBY) position under new circumstances. The Madison County representatives encountered citizens opposing incineration at the very sites that would receive the stockpile if their call for transportation was successful.

In November 1991 the coalition, designated the Chemical Weapons Working Group (hereafter noted as the Working Group), became a reality. KEF organized a conference that drew 25 delegates from proposed incineration sites in Maryland, Alabama, Indiana, Colorado, Utah and Oregon, representatives from the Asian Council of Indigenous Peoples and leaders of a Russian anti-incineration group. Proceeding with the new addition to the local repertoire, the Working Group drafted a position paper titled "The International Citizens' Accords on Chemical Weapons Disposal." Using technical data assembled from experts within the anti-toxics coalition, the Accords proclaimed incineration and other open-ended disposal systems (as opposed to fully contained or "closed-loop" systems) unacceptable and called for expanded citizen involvement in developing alternative solutions.

The first conference of the Working Group signaled decisive changes for the most active of the Kentucky opposition groups. Yet Concerned Citizens remained focused on the option of transportation, which was expressed as both a matter of representing their constituency and one of strategic importance. As a long-time Concerned Citizens member explained,

When we play NIMBY we mean NIMBY. Our responsibility is to Madison 148
Citizen-State Interaction

(Concerned Citizens) have always wanted [the option of transportation] to

remain open... and we haven't changed a bit in that (interview 12/28/94).

But Common Ground and KEF were now the most active and influential groups involved in the controversy. Their primary focus had turned toward federal level decision-making and the formation of the Working Group was being touted as the most politically viable means for affecting this level. Consequently, as a commitment to solidarity was made with groups at the other sites, the NIMBY stance lost much of its former allure to Common Ground and KEF.

A national and intemational focus began to crystallize and a variety of new strategies for challenging the Army's disposal plan were considered. Locally focused actions were being recast and the repertoire of action expanded. The challenge began to resemble a social movement in Tilly's (1978) and Tarrow's (1994) sense of a sustained series of interactions between people claiming common purposes and solidarity and national authority and opponents. Community-based actions were beginning to give way to more broadly focused campaigns as the leading organizations of the movement emphasized the need to fully engage federal decision-making processes. But unlike Tarrow's and Tilly's common emphases on the extra-institutional actions of movements, the citizens' challenge had emerged and remained oriented primarily towards formalized, institutional mechanisms for access to participation in decisions concerning the program.

\section{Expanding Opportunities and New Vulnerabilities}

By $1992 \mathrm{KEF}$ and the Working Group, in conjunction with organizations and experts within their expanding network of affiliations, had begun to marshal the types of technical evidence that the Army had claimed could prompt significant modifications in the entire disposal program. Earlier mechanical problems, operator errors and organizational malfeasance at both the Tooele and Johnston Atoll facilities had provided grounds for highly critical claims against the project. Technical evidence from official reports about the incidents also offered strong bases for arguing against incineration. ${ }^{12}$ Moreover, the

12 For example, KEF and Greenpeace publicized the Army's report on the first test phase of the Johnston Atoll facility. The report, carried out by the MITRE Corporation, concluded that although numerous violations of environmental regulations had occurred, the concluded that although numerous violations of environmental regulations had occurred, the
Johnston Atoll operations were sufficient for the test phase. KEF's and Greenpeace's evaluation of the MITRE report found that numerous technical problems and operational oversights had resulted in alarms, designed to activate in the event of a chemical accident or release, being triggered 165 times during the test period. Less than a month after the MITRE study was released, a fire at the Johnston Atoll facility further confirmed the opposition's concerns. 
transformation in the citizens' stance from exclusively advocating transportation to supporting altemative technologies appeared effective. Evaluations of the disposal program by the opposition's experts and associated data suggesting the workability of several alternatives introduced new, technical forms of discourse and claims-making into the debates surrounding the controversy problematizing the conclusions of the Army's previous environmental impact statements. Technical evidence and the rhetoric of alternative technologies were salient among political leaders and compelled responses at various levels, further expanding political opportunities for the citizens' opposition.

By June 1992 citizens gained their first access to a captive Congressional audience when members of KEF were invited to testify at a federal hearing on the disposal program. Federal level support continued when both the General Accounting Office and the Office of Technological Assessment recommended to Congress that the Army give further consideration of alternative technologies. The recommendations prompted Congress to direct the Army to engage the alternatives issue. Congress deferred $\$ 9.1$ million originally slated for the disposal program from the 1993 Defense Authorization Act and the accompanying Defense Appropriations Bill and prohibited any site preparation or construction until the completion of the Army's review. The expansion of contention to multiple sites involved in the program had sharpened officials' consideration of the issues involved. Combined with the movement's attempts to engage federal-level decision-making processes, citizens had succeeded in altering the legislative agenda toward consideration of their nascent solution-oriented approach.

The delays in the disposal program prompted Common Ground to proclaim 1993 as the "Year of Pause" (Common Sense 12/92). Efforts were made during this period to formalize the inter-organizational structure of the opposition groups. Three distinct tiers now complemented each other in focus and action. Local groups at the sites (e.g. Common Ground and Concerned Citizens) comprised the first tier focused on maintaining local community-based participation and action on the issue. The Kentucky Environmental Foundation (KEF), the second tier, provided fiscal and strategic support serving as an informational hub and the coordinating body for the local groups comprising the Working Group. The Working Group represented the third tier and the national and international face of the opposition. This loosely-coupled inter-organizational structure enhanced the opposition's capacity to address multiple dimensions of the political environment among levels and across localities of the state. The inter-organizational arrangement also enhanced the groups' capacities to extend and transform the action repertoire and amplify the opposition's political influence by creating a unified front, while maintaining the relatively autonomy of groups at each level.

At its second conference in April 1993, the Working Group maintained its focus on alternative technologies and produced another masition paper consisting of a broad-ranging list of preferred congressional actions towards the Army's program. But, on February 7, 1994, almost exactly a decade after the Army announced its baseline plan, the National Research Council released its report on alternative technologies advising the Army to proceed with its plans for on-site incineration recommending only that the facilities employ new pollution control devices (National Research Council 1994).

Local groups, KEF and the Working Group criticized the report for what was seen as an improper evaluation of long-term health risks, lack of objectivity in its selection of data and outside influences. Disputes of this type, between technical experts and supporters of specific technologies, are central to technical controversies. Definitive scientific conclusions are rare (Mazur 1981; Levine 1982). Consequently, allies and supporters for all sides can often be found. Outcomes often rest on and supporters for analysis. The key point of contention of the report was the National Research Council's evaluation of the the reportion of the stockpile. The National Research Council had selected information from the Army's 1988 Programmatic Environmental Impact Statement that indicated the weapons in Madison County were deteriorating and stability was assured only through 2002. An Armycommissioned study by the MITRE Corporation (1993) assured stability through 2019. From these studies, the National Research Council's committee concluded that the risk associated with continued storage was "the same or greater than the annual risk due to disposal" (National Research Council 1994, p.121). The conclusion supported the Army's push for incineration at the time, but the issue of deterioration and risk would soon reappear as a central vulnerability in the Army's stance. The Army presented its final conclusions on altemative technologies to Congress in April 1994. Its decision to continue with on-site incineration was expected. There were also stringent legal and regulatory obstacles at various levels of the state, however, that the Army would first have to overcome. Indeed, Kentucky now had some of the nation's toughest protection standards for hazardous waste incineration. Opponents saw little possibility in the Army meeting these standards.

Following the Army's report the major decisions regarding the budget and time-tables for the program now moved firmly into the congressional arena. It was uncertain whether the citizens' claims had the desired affect of altering the push for on-site incineration. The 

million for research and development of altemative technologies, but both the House Armed Services and Defense Appropriation Committees were recommending the appropriation of almost $\$ 575$ million for further construction of incinerators in 1995. Discrepancies in the claims and actions among officials and agencies of the state remained a central component to the opposition's critical claims regarding the disposal program.

The movement's ensemble of critical claims were amplified during the latter months of 1994. In this pivotal period for the future of the disposal program, two crucial vulnerabilities emerged that boded well for the opposition and cast new doubts on the Army's rhetoric about the efficiency of incineration and the entire disposal program. The first involved the purported deterioration rate of the stockpile. In August 1994, the Army released the preliminary findings of a new risk assessment that showed previous calculations of the deterioration rates were off by more than 100 years. Common Ground, KEF and the Working Group quickly proclaimed the Army's prior emphasis on deterioration rates as misinformation used to bolster the push for incineration. KEF's executive-director claimed,

If the Army cannot be correct in a simple mathematical problem, how can we expect them to oversee an immensely complicated and dangerous project such as the disposal program (interview 8/9/94)? They have misrepresented the realities of the situation and that is unconscionable (Herald-Leader $8 / 11 / 94$ ).

The second event involved the entire incineration program. In early September, new allegations about the disposal program surfaced from Steve Jones, a highly-commended safety officer charged with safetyinspections at the Tooele, Utah chemical weapons incinerator. Jones, fired following his completion of an internal safety audit of the plant, charged the site with over 1,000 safety violations. Problems included lack of safety training, insufficient monitoring of stack emissions, venting of chemical agent directly into the atmosphere and defects in the overall design of the plant itself. The incident piqued concern from Utah to Kentucky, Russia and the Pacific Islands. Utah's Governor Michael O. Leavitt and U.S. Senator Orin Hatch of Utah initiated a state-level investigation into the safety risks at the Tooele plant. The allegations were too controversial for the Army to ignore. Officials quickly announced the beginning of an Army investigation regarding Jones' charges, and the House Armed Services' Oversight and Investigations subcommittee began another investigation.

Prior to the new deterioration report and Jones' allegations, the citizens' prospects for altering the incineration component of the disposal 152
Citizen-State Interaction

program had appeared to be waning. Although, supportive allies and policies at multiple levels of the state were evident and funds had been appropriated for further alternatives research, the National Research Council's recommendations supporting on-site incineration made congressional approval for current continuation of the disposal program seemed likely. But, the critical scrutiny and investigations that emerged around the recent and timely events had, again, altered the political atmosphere surrounding the controversy.

Congressional scrutiny, erroneous claims of deterioration and Jones' whistleblowing also brought increased local, regional and national media attention to the controversy. In an attempt to capitalize on these changes, Common Ground, KEF and the Working Group proposed a new form of action that combined forms selected from the available cultural repertoire. As a display of international solidarity against chemical weapons incineration, the groups organized "The International Day for Safe Disposal." Marches, rallies, demonstrations, press conferences and town meetings, arranged by citizens' groups at each proposed disposal site in the continental U.S., Hawaii and Russia, were held on September 25. The emphasis on "safe disposal" captured the fundamental aim of Common Ground, KEF and the Working Group. The goal of weapons disposal was not the central issue of dispute nor was the location of disposal expressed as the focus. Rather claims centered on the means (incineration) proposed by the Army. In light of the alternatives available the NIMBY stance had been dropped by most groups involved, incineration was touted as unacceptable and alternative solutions were being advocated. Members of the Working Group expressed hope that this new form of action and their solution-oriented approach would further solidify political support at multiple levels of the state and warrant international policy-making against incineration.

By the end of 1994 the actions of KEF and the Working Group were primarily being directed towards influencing federal level decisionmaking processes pertaining to the program. According to key participants in the groups, to be effective at this level demanded increasingly intense, full-time attention to events on Capitol Hill, detailed communication and coordination within the Working Group, ${ }^{13}$ and communication with and continued support of political allies at multiple

13 The Working Group now had 33 member groups in the United States, Russia and among the Pacific Islands. In addition, 77 organizations have officially endorsed the Working Group's anti-incineration position. Among these are the International Union of Pure and Applied Chemistry, Citizens Clearinghouse for Hazardous Waste, GreenLaw, Greenpeace, Government Accountability Project, Sierra Club, Physicians for Social Responsibility and the Pacific Island Association of Non-Government Organizations. 
local level. But since its inception, KEF had been faced with lack of time and personnel to focus on all the political dimensions and issues pertinent to the controversy. They had simply become too numerous to be dealt with on a consistent basis.

Ironically, the important points of leverage that had been gained as a result of the movement's expansion and new increasing emphasis on affecting the federal legislative agenda had created problems in sustaining action within the communities from which the movement had emerged. With the exception of the "International Day for Safe Disposal" local participation had declined. Speaking of the Madison County situation, a KEF member explained,

People in this community...have lost ownership of the information and the issue. Because before when it was just Common Ground people were gathering together to look through information, to figure out how to get the info, gathering contacts, to brainstorm on ideas and strategic moves, to write letters, ho make meetings and things like that. Now we have just one to write letters, hold public people who are doing that on a full-time bast one organization $(\mathrm{KEF})$ or fou People don't have direct on a full-time basis...its like their little piece is gone. People don't have direct involvement anymore. And that's something we are trying to change. But it's been difficult to figure out how to do both. How do you conduct this international movement plus keep things very local (interview
$1 / 4 / 95$ ).

Movement leaders were faced with the dilemma of maintaining an organizational structure "sufficiently robust to stand up to opponents, but flexible enough to... [continue] draw[ing] on energies at the base" (Tarrow 1994, p.136). The executive director of KEF succinctly stated the core problem they faced in late-1994. "The big issue will be won or lost on the national level, but it cannot be won without good organization [and active participation] at the local level" (Common Ground minutes
$11 / 9 / 94)$.

\section{New Solutions or the Status Quo?}

Dual possibilities had emerged with the movement's turn towards emphasizing dimensions of federal action and opportunities. The controversy had been pushed into Congress, the highest level of political decision-making. Now, the fate of the disposal program and incineration rested on the extent to which Congress would approve the program and allocate the necessary resources. Although the ends of disposal would remain intact, extensive Congressional opposition to the disposal program could result in support of the strategies advocated by the movement: alterations in the timeline for disposal, termination of incineration as the technology of choice and intensive development of alternative technologies. On the other hand, there was not another level of the state to which debate and decision-making on the program could be pushed. Congressional support for the disposal program could leave the movement facing a rapidly constricting set of political opportunities. For decisions made at this level would shape, and possibly diminish the political effectiveness of the movement at other levels by closing off further points of debate through new or redefined Congressionallyimposed mandates for action. ${ }^{14}$

Despite this, opponents had reason for optimism that Congressional support for altematives would be forthcoming. Steve Jones' allegations were supported by an independent audit of the Tooele facility that found 3,016 hazards relating to design flaws and operations problems, over 1,000 of which were designated as presenting imminent, catastrophic risk of explosions or nerve agent releases. Army investigations also confirmed many of his charges. The conclusions captured the attention of military leaders, Congressional officials and the national media, including the New York Times and the Washington Post.

The political effects of Jones' allegations were sharpened as further criticisms about the disposal program surfaced in early 1995. In March a former cost-analyst at the Johnston Atoll facility, Charles Oughton, went public with criticisms directed toward the program's cost overruns. He explained,

[The program] has never met a cost estimate or production goal since it started ten years ago. Every time there's a problem, [the Amy] simply change[s] the cost estimates or production schedules. This has to stop. It's a waste of billions in taxpayer dollars (Richmond Register 3/28/95).

The General Accounting Office (GAO 1995) was also critical of the Army's handling of the program, reporting that cost estimates for the program had risen since 1985 from $\$ 1.7$ billion to over $\$ 11$ billion and charged that the Army's figure was understated by as much as $\$ 348$ million. These conclusions furthered opponents' politically-salient criticisms regarding the program. The Working Group, linked the costoverruns to the popular rhetoric of fiscal responsibility that had gained salience among many politicians. A Working Group spokesperson explained, "At a time when the American public and their representatives are demanding fiscal responsibility, this program represents the epitome of open-ended wasteful spending" (Herald-Leader 3/28/95).

${ }^{14}$ Of course there were other possibilities as well. Most likely was that Congress would remain supportive of continued research and development of alternative technologies while continuing the program on its current trajectory until the viability of the alternatives could be sufficiently proven. 
In 1996 the National Defense Authorization Act directed the House of Representatives to hold hearings addressing the current status of the disposal program and measures to reduce overall cost and minimize environmental risks. On July 13, 1995 Army spokespersons, political officials and representatives from KEF, the Working Group and the Kentucky Citizens' Advisory Commission testified before a House National Security subcommittee. Drawing on prior expert testimony and scientific data gained through the opposition's growing network of environmental groups, technical advisors and scientists, citizen representatives presented detailed technical support for their highly critical claims of the disposal program and the potential of alternative technologies. ${ }^{15}$ Ironically, some House members even resurrected the politically contentious option of reducing costs by transporting stockpiles to existing facilities. Following the hearing, the House subcommittee approved a Department of Defense plan for establishing a study group made up of political officials and representatives from the Army, Department of Defense, Chemical Stockpile Emergency Preparedness Program, National Research Council and citizen groups including the Working Group and Citizen Advisory Commissions. Yet another point of access to officials and agencies with authority at multiple levels and across localities of the state had emerged.

The hearing reportedly was seen as an indication of expanding interest of Congress in the program, practical action, and positive political shifts toward the citizens' opposition to the disposal program. Craig Williams, spokesperson for the Working Group, defined the study group as a step forward in the controversy. "[The hearing] wasn't a home run, but we are definitely on the field and in the game. The dynamics of the program are clearly changing" (Berea Citizen 7/27/95). At the Working Group's 1995 meeting delegates released to media outlets and Working Group member groups, the most sophisticated and extensively documented position paper yet developed by the citizens and circulated within Congress. ${ }^{16}$ Following the conference and an associated press

${ }^{15}$ New information on alternatives was emerging both from the Army's investigations as well as outside the Department of Defense research labs. Advances in technologies based on a number of chemical and biological neutralization processes (Yang 1995), Molten Metal Pyrolosis, Hydrogenation and Electrochemical Oxidation (Department of Defense 1996).

16 "The Citizens' Solution to the Costly Mistake of Incineration" detailed information on the cost overruns of the disposal program, public health issues, problems with the Chemical Stockpile Emergency Preparedness Plan, safety considerations at the Tooele depot, legal issues associated with the program and the most current data on alternative technologies for disposal. conference and Congressional briefing, delegates were described as feeling that "Congress [was] beginning to realize that [the citizens] are looking for solutions, not trying to delay the program" (Common Sense $7 / 95$ ). As one member put it, "we are no longer being dismissed as obstructionists with no hope of really impacting the status quo" (Common Sense 7/95). ${ }^{17}$

The movement's emphasis on action directed toward the federal level had provoked decision-making at the highest level of the state. U.S. policy on chemical weapons disposal would follow from Congressional actions toward the program. The disposal issue was, however, also an international concem. The tentative 1989 bi-lateral agreement between Russia and the U.S. on chemical demilitarization had resulted in close financial and political ties that would shape the fate of the two programs. These ties provided the movement another dimension along which to expand participation, orient claims-making and offer solutions. Claims could now emphasize the broad, indeed global, implications of the United States' approach to chemical weapons disposal.

Aware of these implications, the Working Group and CEC International Partners held the first Russian-American NonGovernmental Organization Summit on Chemical Weapons Disposal in Saratov, Russia on October 20-22, 1995. Following the pattern of prior Working Group conferences, representatives from chemical weapons disposal sites in Russia and delegates from all the U.S. sites met to create a position paper, the "Intemational Citizens Declaration on Chemical Weapons." The Declaration emphasized the need for citizen participation in decisions regarding disposal and the viability of alternative technologies. These emphases were punctuated by Russia's decision in 1995, prior to the Summit, to reject a disposal program based on incineration in favor of chemical neutralization technology. As spokespersons for the Working Group had remarked before the conference, "The irony is that the United States will subsidize a Russian neutralization program that has support in this country (U.S.), while relying on an incineration plan that has virtually no political support" (Herald-Leader 5/16/95). The Summit was central in the movement's

${ }^{17}$ As 1995 proceeded the opposition maintained a guarded optimism. It was expected that the new information about the Amy's operation of the disposal program would have important 1996 Defense legislation and subsequent funding of the disposal inportant effects on 1996 Defent program. Legal obstacles to the advancement of the disposal program based on incineration have been pursued at all sites. Lawsuits by the Working Group, the Pacific Asia Council of Indigenous Peoples and the Institute for the advancement of Hawaiian Affairs have been filed opposing reissuance of EPA operating permits for the Johnston Atoll facility. Steve Jones also named the Amy as a defendant in his illegal termination lawsuit being considered by the U.S. Labor Department. 
efforts to magnify the importance of the ties between the countries and politically exploit the discrepancies between the programs to encourage Congressional action towards alternative technologies for the U.S. disposal program.

Although alternative technologies were being developed, the Army had maintained its focus on incineration citing Congressional deadlines and the unproven qualities of the alternatives for a large-scale disposal program. But, in June $1996,{ }^{18}$ it appeared that incineration opponents would get Congressional action that would pave the way to the thorough consideration of alternatives to incineration they had called for. Kentucky Senator Wendell Ford announced his plans to introduce legislation that would halt all current action on developing incineration facilities while the Army and the Department of Energy conducted a three year, $\$ 60$ million pilot program for testing alternative technologies. The legislation would effectively eliminate the current timeline for the disposal program. KEF and the Working Group were very supportive, calling the move ..."the greatest thing that has ever happened in this program if we can get it through" (Register 6/10/96, emphasis added).

The remark was prescient. The Senate gave full approval of the plan in June. Congress dismantled its central provisions three months later. Rather than requiring a pilot program to test alternatives, the bill that emerged from House and Senate negotiations instead gave the Department of Defense one year to study whether such a pilot program was needed. But, three days later Congress passed legislation introduced by another Kentucky Senator, Mitch McConnell. McConnell's program authorized Congress to spend $\$ 40$ million to investigate alternatives in a pilot program very similar to the one proposed by Ford. The plan would also prevent the Army from beginning construction of an incinerator facility in Kentucky until six months after a report on the pilot program had been presented to Congress. The plans proposed by the Kentucky Senators were similar in many respects except that McConnell's legislation omitted Senator Ford's proposal to eliminate the Congressional timeline for weapons disposal. While reasons for one being approved over the other are numerous, this may have been a key compromise that facilitated the bill's passage. McConnell's position on the Appropriations Committee and as one of the negotiators who worked out the final version of the bill was also vital to its passage. Ford had been excluded from closed-door negotiations.

${ }^{18}$ Common Ground, KEF and the Working Group had maintained lobbying efforts at local, state and federal levels and continued to pursue numerous legal obstacles to the disposal program throughout the first half of 1996.
Citizen-State Interaction

This explanation points to an important aspect of the role of political allies as a dimension of opportunity. The appearance of multiple allies at each level of the state is a critical indication of potential for effective collective action. But, the manner in which those allies influence political processes may be significantly affected by the institutional positions they control with respect to the issues being addressed. McConnell's role in negotiations on the bill provided the chance to clarify and strengthen arguments for the bill's passage. Ford's exclusion vastly limited this possibility.

It was likely that the omission was also linked to the Army's actions on the disposal program, during the time in which Ford's proposal was being negotiated. On Thursday August 22, 1996 the Tooele, Utah incineration facility was brought on-line and began destroying agentbearing rockets. Two days later a chemical agent leak during processing was reported and incineration was halted. Precedent had been set. The Tooele facility was operating, but the future of the United States Chemical Stockpile Disposal Program remained unclear.

As 1996 drew to a close the newest transformation in the opposition's objectives appeared solid. The fundamental goal of halting the on-site incineration component of the disposal program and the emphasis on safe disposal remained. The opposition had moved toward explicitly and expertly addressing what many participants some have come to see as the underlying and most fundamental issue of this extended controversy - developing a framework for citizen participation in a new democratic politics of technology. The transformation promises to usher in further phases of the controversy.

\section{Discussion and Implications}

Through successive periods of the controversy, the citizens' challenge to the disposal program has exhibited numerous transformations in claims-making, forms of action, organizational structure and the expressed aims of the groups involved. These transformations emerged, in part, as adaptive responses to changes in dimensions of political opportunity located at multiple levels of the state and to vulnerabilities in the actions of the Army and associated agencies of the state. On the other hand, political opportunities were, in part, purposefully sought and developed by the movement groups over several phases of the controversy. I will now discuss these transformations in light of what they may explain about the nature of technical controversy and the state. I also suggest some ways that the concepts used in this analysis might be refined. 
Contemporary political challengers act to establish a pattern of consultation with policy makers and win advantages and favorable policy decisions (Lo 1992). ${ }^{19}$ The study of social movements and collective action has emphasized that challengers predominately employ "unconventional", extra-institutional actions that draw primarily on community-based resources such as time and commitment of citizens (Lo 1992, pp.235, 238). Undoubtably, community-based resources and extra-institutional actions have been important in the dispute over the Chemical Stockpile Disposal Program. The controversy over the disposal program began as a local dispute relying on people and resources located within the local communities surrounding the Blue Grass Army Depot in Madison County, Kentucky. But, as I have emphasized, over the course of the controversy the actions of citizens were significantly shaped by influences external to the citizens' groups. Guidelines based on the National Environmental Policy Act of 1969 (NEPA) provided the framework within which the Army was required to pursue implementation of the disposal program. NEPA mandates for public meetings and citizen participation facilitated the emergence of local action opposing the disposal program by providing occasions for citizens and political officials to engage the Army, make claims and, in principle, take part in decision-making regarding the disposal program. Indeed, these institutionalized processes appeared to provide precisely the "routine, low cost access" to policy-makers and decision-making processes that challengers are said to reference. Consequently, throughout much of the dispute, citizen's actions focused on institutionalized processes for influencing the trajectory of the disposal program.

Focusing on dimensions of political opportunity in this case suggests that particular attention should be directed to the location of these opportunities among levels, localities, agencies and actors of the state. As citizens, officials, the Army and other agencies of the state addressed claims regarding the disposal program, collective action was differentially directed and redirected toward the multiple points of access that were provided by institutionalized channels for participation, sought by movement groups, and that became available through the actions of political allies over the course of controversy. New community organizations were developed, state agencies and officials directed attention toward the disposal program and movement action shifted repeatedly as new, and sometimes unforeseen, transformations in the

19 Lo acknowledges that a once a movement is established it can (and often will) consist of a highly complex blend of challengers and established polity members that draw consis strength and resources from one another.
Citizen-State Interaction

controversy emerged. Early support for citizen concerns by Kentucky officials at both local and state levels resulted in rigid policy standards for weapons disposal at both the local and state level that strengthened federal requirements and altered the trajectory of the program. Delays in the disposal program were created and the Army was obliged to express consideration of transportation and other possible alternatives. But, the Draft and Final Programmatic Environmental Impact Statements did not show fundamental changes in the Army's plans. As the controversy proceeded, federal level decision-making processes became a primary target and means of access for the citizens' opposition. The Army's attempt to limit debate on the program to technical evidence and the site-specific impact statements, also led to transformations in the actions, claims and the organizational structure of the movement. As participation expanded among localities involved in the disposal program, multiple points of access were used, new political allies were gained at each level of the state and scrutiny of the program among agencies of the state intensified. Movement organizers adapted to the expanding dimensions of opportunity by developing a three-tiered organizational structure comprised of groups focused on local, national, and eventually international political processes. The loosely-coupled arrangement between the local groups, KEF and the Working Group enabled the opposition to coordinate actions among the different sites and address the multiple points of access that were gained over the course of the dispute. Emphasis was also given to maintaining the flexibility and autonomy of each local organization as strategies for influencing new allies linked to each site were decided by the movement organizations at those sites.

The conceptualization of influential allies as an element of opportunity consists of several dimensions. The sheer number of political allies supporting a movement may be important for moving the issue(s) being disputed into political discourse and provoking scrutiny. More importantly, leverage may be enhanced when the allies occupy positions at multiple levels of the state and across localities. This configuration provides the movement several points of access through which to influence political policies and regulations affecting the issue under dispute. This appears to be especially important in technical controversies involving projects planned by agencies of the state to be implemented at several sites or that involve conditions relevant to a number of separate locales. Formidable legal and other regulatory obstacles to developing a controversial project may be erected by allies at each level and at each locale. But, the potential is even more complex. Another important consideration is the different means by which the positions occupied by those allies allow them to influence political processes surrounding the issue. As the failure of Senator Ford's 
legislation and the passage of Senator McConnell's demonstrated, there are important variations of some allies' influence. These differences deserve scrutiny as they may have far reaching effects on further actions and developments over the course of controversy.

Tilly (1978) and Tarrow (1994) lead us to expect that an expansion in state authority over areas not formally regulated, provides opportunities for challengers. The National Environmental Policy Act of 1969 has done just this. Tarrow then seems to suggest that as the state extends authority, it becomes a "fulcrum" for claims and challenges against autonomous actors outside its institutional boundaries. This case suggests that Tarrow's description of the state as "fulcrum" through which claims against autonomous actors outside its institutional boundaries are made should be extended. The dispute over the disposal program demonstrates that the laws and regulations of the state may also be used to counter actions within the boundaries of institutional politics by allowing movements, actors and agencies of the state to challenge and constrain the actions and goals of other agencies of the state. Hence, a more inclusive conceptualization of the linkage between dimensions of political opportunities and the state should reflect the possibility of conflict and struggles between aims and goals of officials and agencies of the state itself. The manner in which these tensions develop may be central for understanding major effects on the organization, direction and endurance of movement action. Over the course of this controversy NEPA provided the framework for the actions of both the Army and the movement. But the conflicts that emerged among officials and agencies of the state strongly conditioned the action of the movement to be directed primarily through institutional channels. Potential opportunities through which to affect political processes repeatedly opened. This conclusion broadens the already complex scope of interests and actions that should be considered in examining citizen-state interaction.

Political opportunities were not, however, the only factors external to challengers that have been important for sustaining movement action and access to policy-making processes. Human errors and technical problems associated with the disposal program emerged throughout the controversy, leaving the Army vulnerable to highly critical claims by citizens and officials. Claims emerged regarding inadequacies of the Army's technology and the plausibility of alternative technologies and were combined with growing concerns over Army negligence and citizens' exclusion from effective participation in the decisions regarding the program. Taken together, these claims helped widen the dimensions of opportunity open to the challengers. Officials and regulatory agencies were prompted to further assess the Army's management of the disposal program which, in turn, pushed political discourse and scrutiny into areas
Citizen-State Interaction

previously unexamined. New allies were gained as evidence of technical problems and cost overruns mounted and as new solutions were advanced by the opposition groups and their experts.

Actions, claims-making and goals of movements are constructed on shifting and emergent grounds (Weller 1994). "One encounter with authority [is] succeeded by other encounters, each with a different effect..." (Turner and Killian [1957] 1987, p.255). Consequently, forms of action, claims-making, organization and goals are subject to change throughout the life of the movement (Walton 1992; Weller 1994). In this case, the flexible organizational structure of the movement and adaptations in aims and actions have helped the challengers to sustain interaction with the Army and political officials at multiple levels and across locales of the state. The expansion of the opposition's repertoire of action and claims-making, in conjunction with the ability of the movement to combine different elements according to the actions and opportunities presented by the Army, political allies and dictates of state policies, has given the opposition much of its potency. The formation of the Chemical Weapons Working Group had particularly significant effects on the dispute. The national coalition enhanced the political saliency of the opposition while altering the solutions advocated and actions pursued on the local level. Combined with the Army's attempt to limit debate to technical considerations following the Final Programmatic EIS, the movement began to employ experts and technical claims of the workability of alternatives to incineration. Consequently, the Working Group and others began to advance a position that no longer merely opposed the Army's project, but instead emphasized solutions to solve the problem of chemical weapons disposal. This approach was consistent with earlier claims of a lack of public participation in decisions regarding the disposal program. The goal of disposal was not at issue. Instead, it was the means by which the weapons were to be destroyed and the manner in which decisions regarding the program had been made. Combined with the repeated technical problems at the Tooele and Johnston Atoll sites, these claims of alternative means increased support among political officials and other allies and new policies affecting the trajectory of the disposal program were developed.

Charles Perrow (1984) argues that the increasing complexity of highrisk technologies, especially those with catastrophic potential such as chemical weapons incineration, makes these technologies prone to mechanical failures and human errors. The Army's technical difficulties shouldn't be surprising as Perrow (1984) suggests they are quite "normal." As in this case, technical problems and expert opposition may be advanced as opportunities for influencing political allies and arousing public concerns (Walsh 1986) by exposing proponents of technologies to 
critical claims based on these problems as well as on the escalating costs of redesigned technical programs. The claims can, in turn, play an important part in facilitating and sustaining participation in movement actions during these disputes by exposing empirical evidence of inadequacies in the technology and planning of these projects. But, in addition to the technical and operator problems that left the Army open to critical claims-making, Army officials were repeatedly inconsistent in their stance towards alternatives to on-site incineration. Positions wavered between the workability of transportation and the "necessity" of on-site incineration. The apparent indecisiveness, inconsistencies, and contradictions among Army officials and associated agencies of the state repeatedly entered the discourse and claims-making of the opposition. The disposal program was charged with being disorganized and ineffective and the Army as indifferent to public concerns. In light of these issues I suggest an additional consideration to Walsh's useful idea. That is, for targets in technical controversies maintenance of, at least, the appearance of command, competence and control over a technology is significant for shaping the trajectory of disputes. When these disputes involve agencies of the state, organizational consistency and preparedness during processes such as those circumscribed by NEPA and in interactions with authorities, officials and citizens, can be pivotal to the rise and fall of controversy.

Although the foci of political opportunities, target vulnerabilities and repertoires of action do not capture the immense complexity and dynamism of this controversy, the concepts do illuminate important factors shaping action through successive phases of the movement: A question outside of this study that remains is to what degree of political action must citizens go to advance their claims in the face of programs such as the Chemical Stockpile Disposal Program that carry the potential of catastrophic consequences. This question is especially salient regarding technical controversies and the state. Lay challengers may face the daunting task of marshaling complex technical and scientific data and experts that support their claims to contest projects proposed by agencies of the state with vast networks of resources from which to draw upon. But, outcomes are not necessarily pre-determined by this uneven access to resources and expertise. Unexpected courses of action may develop. Target vulnerabilities may emerge as a significant feature of claimsmaking and the growth of challenges toward the project. Equipped with a set of critical claims that suggest numerous inadequacies linked to a program such as the Chemical Stockpile Disposal Program, citizens may work from within institutional channels, exploiting the regulatory processes to their own ends. Instead of challenges emerging outside the confines of institutional politics as Tilly, Tarrow, Lo and others appear to understand the development of movements, protest may emerge and
Citizen-State Interaction

remain primarily confined to institutionally mandated channels for participation. This certainly does not exclude the possibility of the emergence of "unconventional," extra-institutional actions. It instead suggests that the social, political and scientific context of technical controversies and the state, may place constraints upon and opportunities for action producing patterns of movement emergence dissimilar to movements associated with other issues.

\section{References}

Benford, Robert D., Helen A. Moore, and J. Allen Williams, Jr. 1993. "In Whose Backyard?: Concem About Siting a Nuclear Waste Facility." Sociological Inquiry 63:32-48.

Bosso, Christopher. 1991. "Adaptation and Change in the Environmental Movement." Pp. 151-76 in Interest Group Politics, edited by Allan J. Ciglar and Burdett A. Loomis. Washington, D.C.: Congressional Quarterly Press.

Brown, Phil and Susan Masterson-Allen. 1995. "The Toxic Waste Movement." Society and Natural Resources 7:269-287.

Cable, Sherry and Michael Benson. 1993. "Acting Locally: Environmental Injustice and the Emergence of Grass-roots Environmental Organizations." Social Problems 40:464-477.

Capek, Stella M. 1993. "The 'Environmental Justice' Frame: A Conceptual Discussion and Application." Social Problems 40:5-24.

Clarke, Lee. 1990. "The Political Ecology of Local Protest Groups." Pp. 83-111 in Communities at Risk, edited by Stephen Robert Couch and J. Steven Kroll-Smith. New York: Peter Lang.

Code of Federal Regulations. 1991. Parts 630 to 699. Office of the Federal Register, National Archives and Records Administration. Washington, D.C.: Government Printing Office.

Congressional Quarterly. 1970 Almanac, 91st Congress, 1st session...1969, XXV. Washington, D.C.: Congressional Quarterly.

Davies, Carol Griffith. 1995. The Dialectics of Power and Dissent: $A$ Study of the U.S. Army's Chemical Stockpile Disposal Program. Ph.D. dissertation, Department of Sociology, University of Tennessee, Knoxville. 
Department of the Army. 1991. Federal Code of Regulations. Washington, D.C.: Office of Federal Register National Archives and Records Administration.

Department of Defense. 1996. Interim Status Assessment for the Chemical Demilitarization Program. Washington, D.C.: Department of Defense.

Gamson, William A. and David S. Meyer. 1996. "Framing Political Opportunity." Pp. 41-61 in Comparative Perspectives on Social Movements, edited by Doug McAdam, John McCarthy and Mayer N. Zald. Cambridge: Cambridge University Press.

Gerlach, Luther P. 1983 "Movements of Revolutionary Change: Some Structural Characteristics." Pp. 133-47 in Social Movements of the 1960's and 1970's, edited by Jo Freeman. New York: Longman.

Gibbs, Lois Marie. 1982. Love Canal: My Story. Albany: State University of New York Press.

Hindman, Douglas. 1989. "Public Input to the Chemical Stockpile Disposal Program NEPA Process." The Environmental Professional 11:291-296.

Jasper, James M. 1988. "The Political Life Cycle of Technological Controversies." Social Forces 67:357-377.

Kraft, Michael E. and Norman J. Vig. 1990. "Environmental Policy from the Seventies to the Nineties: Continuity and Change." Pp. 3-31 in Environmental Policy in the 1990's, edited by Norman J. Vig and Michael E. Kraft. Washington, D.C.: Congressional Quarterly Inc.

Lester, James P. 1990. "A New Federalism? Environmental Policy in the States." Pp. 59-79 in Environmental Policy in the 1990's, edited by Norman J. Vig and Michael E. Kraft. Washington, D.C.: Congressional Quarterly Inc.

Levine, Adeline Gordon. 1982. Love Canal: Science, Politics and People. Lexington, MA: Lexington Books.

Lo, Clarence. 1992. "Communities of Challengers in Social Movement Theory." Pp. 224-47 in Frontiers in Social Movement Theory, edited by Aldon D. Morris and Carol McClurg Mueller. London: Yale University Press.

Mazur, Allan. 1981. The Dynamics of Technical Controversy. Washington, D.C.: Communications Press, Inc.

McCarthy, John D. and Mayer N. Zald. 1977 "Resource Mobilization and Social Movements: A Partial Theory." American Journal of Sociology 82:1212-1241.

National Research Council. 1984. Disposal of Chemical Munitions and Agents. Washington D.C.: National Academy Press.

National Research Council. 1994 Recommendations for the Disposal of Chemical Agents and Munitions. Washington, D.C.: National Academy Press.

Nelkin, Dorthy (ed.). 1984. Controversy: Politics of Technical Decisions. Beverly Hills, CA: Sage.

Oliver, Pamela E. and Gerald Marwell. 1992 "Mobilizing Technologies for Collective Action." Pp. 251-72 in Frontiers in Social Movement Theory, edited by Aldon D. Morris and Carol McClurg Mueller. London: Yale University Press.

Perrow, Charles. 1984. Normal Accidents: Living With High Risk Technologies. New York: Basic Books, Inc.

Portney, Kent E. 1991. Siting Hazardous Waste Treatment Facilities. New York: Auburn House.

Powell, Stephen J. 1984. Political Difficulties Facing Waste-to-Energy Conversion Plant Siting. Los Angeles: California Waste Management Board.

Robinson, J.P. Perry. 1993. "Origins of the Chemical Weapons Convention" Pp. 37-54 in Shadows of Substance: The Chemical Weapons Convention, edited by Benoit Morel and Kyle Olsen. Boulder: Westview Press.

Snow, David, E. Burke Rochford Jr., Steven K. Worden and Robert D. Benford. 1986 "Frame Alignment Processes, Micromobilization and Movement Participation." American Sociological Review 51:464-481. 
Tarrow, Sidney. 1994. Power in Movement: Social Movements, Collective Action and Politics. Cambridge: Cambridge University Press.

Tarrow, Sidney. 1989. "Struggle, Politics and Reform: Collective Action, Social Movements and Cycles of Protest." Cornell University, Westem Societies Paper no. 21.

Tilly, Charles. 1978. From Mobilization to Revolution. Reading, MA.:Addison-Wesley Publishing Company.

Turner, Ralph H. and Lewis M. Killian. 1987 [1957]. Collective Bebavior. Englewood Cliffs: Prentice-Hall, Inc.

United States General Accounting Office. 1995. "GAO Interim Report GAO/NSIAD-95-66R, 'Chemical Stockpile Disposal Program Review'." Washington, D.C.: General Accounting Office.

Vig, Norman J. 1990. "Presidential Leadership: From the Reagan to the Bush Administration." Pp. 33-58 in Environmental Policy in the $1990^{\prime}$, edited by Norman J. Vig and Michael E. Kraft. Washington, D.C.: Congressional Quarterly Inc.

Walsh, Edward, Rex Warland and D. Clayton Smith. 1993 "Backyards, NIMBYs and Incinerator Sitings: Implications for Social Movement Theory." Social Problems 40:25-38.

Walton, John. 1992. Western Times and Water Wars: State, Culture and Rebellion in California. Berkeley: University of Califomia Press.

Weller, Jack. 1994 "Describing and Analyzing Social Actions of Social Movements." Unpublished.

Wenner, Lettie M. 1990. "Environmental Policy in the Courts" Pp. 189210 in Environmental Policy in the 1990's, edited by Norman J.Vig and Michael E. Kraft. Washington, D.C.: Congressional Quarterly Inc.

Yang, Yu-Chu. 1995. "Chemical Reactions for Neutralising Chemical Warfare Agents". Chemistry or Industry May:334-337.

\section{THE CONTINUITY OF VIOLENCE IN THE STAGES OF THE SHI-SHI MOVEMENT OF NINETEENTH-CENTURY JAPAN}

\author{
YUICHI TAMURA \\ University of Kansas
}

MARS/Social Thought \& Research, 1997, Vol. 20, No. 1-2

\begin{abstract}
Some scholars place violence as prominent in an early stage of a social movement, whereas others argue that violence is characteristic of a later stage. This paper addresses the question of whether there is a specific movement stage that is particularly characterized by violence through an analysis of the shi-shi movement (1858-1864). The shi-shi movement belped create the revolutionary situation which culminated in Japan's Meiji Restoration (1868). Violence was prominent and consequential in the shishi movement and was found throughout the career of the movement. This study of a single case is by no means sufficient to claim primacy over existing models of the place of violence in social movements. The shi-shi movement, however, significantly varies from theoretical models that link violent actions to a specific movement stage.
\end{abstract}

Social movements have careers. They go through stages as they emerge, develop, and decline. Scholars have characterized successive stages of social movements as indicated by the forms of action found in each stage. Violence is one of the indicators used to identify the action said to typify particular social-movement stages. In this paper, I examine the pattern of violence in stages of the shi-shi movement in 19th century Japan in comparison with two ways in which scholars have linked violence to phases of social movements.

Violence is one type of action often associated with social movements. Research on violent actions in social movements mainly addresses two issues. One line of exploration focuses on the causes of violent actions. For example, violence has been explained as an effect of relative deprivation (Gurr 1970; Davies 1962), resource allocations (McCarthy and Zald 1977; Oberschall 1973, 1993) or political conditions (Snyder 1979; Snyder and Tilly 1972; Tilly 1978; Tilly et. al. 1975). The other issue concerns the phase of a social movement in which violent 